\title{
USE OF CRYOPRESERVED SPERMATOZOA FOR CAPRINE IN VITRO FERTILIZATION (IVF)
}

\author{
A.A.Simplicio ${ }^{1,2}$, B.G.Brackett ${ }^{1}$, and L.Keskintepe ${ }^{1}$
}

IDepartment of Physiology \& Pharmacology, College of Veterinary Medicine, The University of Georgia, Athens, Georgia 30602; ${ }^{2}$ Brazilian Agricultural Research Agency National Goat Research Center, PO Box D-10, Sobral, Ceara, Brazil.

Feasibility of using frozen-thawed semen in caprine IVF outside the breeding season was investigated. Two Nubian and 1 Nubian-Boer bucks were electroejaculated. Sperm were washed 2x (Proc.Rec.Adv. in Goat Prod. 2:1089-1094), frozen in skim milk (Brazilian Soc.Anim.Reprod. 171-177), or in egg-yolk (World Rev.Anim. Prod. 8:80). Oocytes with 2-4 layers of cumulus cells from 3-6 mm follicles washed in Tyrode's with pyruvate and PVA, were incubated in $1 \mathrm{ml}$ of Hepes-TCM-199 + $10 \mu \mathrm{g}$ oFSH and $10 \mu \mathrm{g}$ bLH (NHPP, NIDDK, $\mathrm{NICHD}, \mathrm{USDA}) / \mathrm{ml}+20 \% \mathrm{FBS}(\mathrm{MM})$ at $38.5^{\circ} \mathrm{C}$. After $4.5 \mathrm{~h}$ oocytes were further incubated $\left(23 \mathrm{~h}\right.$ ) in $75 \mu \mathrm{l}$ of $\mathrm{MM}$ under paraffin oil and $5 \% \mathrm{O}_{2}, 5 \% \mathrm{CO}_{2}, 90 \% \mathrm{~N}_{2}$. Frozen sperm were thawed in a water bath $\left(37^{\circ} \mathrm{C}, 15 \mathrm{sec}\right)$, and selected by swim-up. IVF was in $\mathrm{mDM}$ (Theriogenology 37:1049-1060), supplemented as below, for $24 \mathrm{~h}$. Embryo culture was in 50 $\mu \mathrm{l}$ of c-SOF+NEA (Biol. Reprod. 55:333-339) for $9 \mathrm{~d}$. Data analysis was by ANOVA and Bonferroni t-test. Percentages of oocytes exposed to heparin-capacitated (HC) sperm that reached cleavage (C), morula (M), blastocyst (B), and expanded B (EB) were 82.8, 57.1, 35.7, $30.0 \%$, respectively; without heparin treatment of sperm data for C, M, B, EB were 44.3, 31.4, $18.6,8.6 \%$, respectively. Further work employed HC sperm. Use of cryopreserved sperm with BSA for IVF yielded no C. Although extenders containing 8 to $20 \%$ egg-yolk enabled good motility after crypreservation in vitro fertilizing ability was lost in our conditions. By contrast, commercial semen processed in season with egg-yolk was effective for IVF (see table).

Table. Caprine IVF with Cryopreserved Spermatozoa

\begin{tabular}{|c|c|c|c|c|c|c|}
\hline \multirow[b]{2}{*}{$\begin{array}{l}\text { Freezing } \\
\text { extender }\end{array}$} & \multirow[b]{2}{*}{$\begin{array}{l}\text { Suppl.of } \\
\text { IVF } \\
\text { medium }\end{array}$} & \multirow[b]{2}{*}{$\begin{array}{c}\text { No. of } \\
\text { oocytes } \\
\text { inseminated }\end{array}$} & \multicolumn{4}{|c|}{ Development stages / Inseminated oocytes (\%) } \\
\hline & & & $\begin{array}{c}\text { Cleaved } \\
48 \mathrm{~h}\end{array}$ & $\begin{array}{c}\text { Morula } \\
120 \mathrm{~h}\end{array}$ & $\begin{array}{c}\text { Blastocyst } \\
\text { (B) } \\
168 \mathrm{~h}\end{array}$ & $\begin{array}{c}\text { Expanded } \\
\text { B } \\
216 \mathrm{~h}\end{array}$ \\
\hline Skim Milk & $\mathrm{LS}^{1}$ & 40 & $33(82.5)^{\mathrm{a}}$ & $20(50.0)^{d}$ & $12(30.0)^{\mathrm{h}}$ & $9(22.5)^{1}$ \\
\hline Skim Milk & FCS & 37 & $4(10.8)^{b}$ & $1(2.7)^{\mathrm{e}}$ & $0^{\mathrm{i}}$ & $0^{\mathrm{m}}$ \\
\hline Egg Yolk $C^{2}$ & LS & 41 & $24(58.5)^{c}$ & $11(26.8)^{f}$ & $7(17.1)^{\mathrm{j}}$ & $4(9.7)^{n}$ \\
\hline Egg Yolk C & FCS & 38 & $6(15.8)^{b}$ & $4(10.5)^{g}$ & $3(7.9)^{\mathrm{k}}$ & $0^{\mathrm{m}}$ \\
\hline
\end{tabular}

${ }^{1}$ Lamb serum. ${ }^{2}$ Sperm processed in season in egg yolk commercially. ${ }^{2}$ Different superscripts in the same column denote significant differences $(\mathrm{P}<0.05)$.

Highest proportions of blastocysts resulted after sperm cryopreservation in skim milk extender, heparin capacitation, and insemination in media containing lamb serum. 